\title{
Tasiamide $F$, a potent inhibitor of cathepsins D and $E$ from a marine cyanobacterium
}

\author{
Fatma H. Al-Awadhi ${ }^{\text {a,b }}$, Ranjala Ratnayake ${ }^{\mathrm{a}, \mathrm{b}}$, Valerie J. Paul ${ }^{\mathrm{c}}$ and Hendrik Luesch ${ }^{*, a, b}$ \\ ${ }^{\mathrm{a}}$ Department of Medicinal Chemistry, ${ }^{\mathrm{b}}$ Center for Natural Products, Drug Discovery and Development (CNPD3), University of \\ Florida, Gainesville. ${ }^{\mathrm{c}}$ Smithsonian Marine Station, Fort Pierce, Florida, USA
}

*Corresponding author. E-mail: luesch@cop.ufl.edu

\begin{abstract}
In search of novel protease inhibitors with therapeutic potential, our efforts exploring the marine cyanobacterium Lyngbya sp. have led to the discovery of tasiamide F (1), which is an analogue of tasiamide B (2). The structure was elucidated using a combination of NMR spectroscopy and mass spectrometry. The key structural feature in $\mathbf{1}$ is the presence of the Phe-derived statine core, which contributes to its aspartic protease inhibitory activity. The antiproteolytic activity of $\mathbf{1}$ and $\mathbf{2}$ was evaluated in vitro against cathepsins D and $\mathrm{E}$, and BACE1. Tasiamide $\mathrm{F}(\mathbf{1})$ displayed $\mathrm{IC}_{50}$ values of 57 $\mathrm{nM}, 23.1 \mathrm{nM}$, and $0.69 \mu \mathrm{M}$, respectively, indicating greater selectivity for cathepsins over BACE1 compared with tasiamide B (2). Molecular docking experiments were carried out for compounds $\mathbf{1}$ and 2 against cathepsins $\mathrm{D}$ and $\mathrm{E}$ to rationalize their activity towards these proteases. The dysregulated activities of cathepsins $\mathrm{D}$ and $\mathrm{E}$ have been implicated in cancer and regulation of immune responses, respectively, and these proteases represent potential therapeutic targets.
\end{abstract}

\section{Keywords}

Natural products, marine cyanobacteria, protease inhibitors, cathepsins D and E, molecular docking

\section{Introduction}

Marine cyanobacteria are known to produce a plethora of structurally diverse bioactive compounds. The structural diversity of cyanobacerial secondary metabolites is attributed to their biosynthetic machinery, which can integrate both non-ribosomal peptide synthetases (NRPS) and polyketide synthases (PKS). The broad spectrum of cyanobacterial metabolites often translates into a wide array of biological activities. Many cyanobacterial metabolites are linear or cyclic modified peptides and depsipeptides with a propensity to inhibit various proteases with different potency and selectivity profiles. Examples of cyanobacterial compounds that have been found to inhibit proteases include: grassypeptolide A which inhibits the dipeptidyl peptidase 8 (DPP8), ${ }^{1}$ gallinamide A (symplostatin 4) targeting cathepsin $\mathrm{L}^{2}{ }^{2}$ and the potent elastase inhibitors lyngbyastatins $4-100^{3-6}$ A group of cyanobacterial protease inhibitors contain a characteristic statine ( $\gamma$-amino- $\beta$-hydroxy acid) unit, which was first described in pepstatin $\mathrm{A}^{7,8}$ and was found to confer activity towards aspartic proteases. Grassystatins A-C, bearing a Leu-derived statine core, isolated from Lyngbya cf. confervoides, were found to be potent inhibitors of cathepsins D and E. ${ }^{9}$ On the other hand, tasiamide B (2), containing a Phe-derived statine unit, isolated from the marine cyanobacterium Symploca sp., was found to inhibit $\beta$-site amyloid precursor protein cleaving enzyme 1 (BACE1) in addition to cathepsins D and E. ${ }^{10,11}$ The dysregulated activity of aspartic proteases has been associated with several diseases, and these proteases may represent important therapeutic targets. BACE1 for instance, is a potential therapy target for Alzheimer's disease (AD) as it generates $\beta$-amyloid (A $\beta$ ) plaques, key players in the pathogenesis of $\mathrm{AD}$, by cleaving amyloid precursor protein (APP). ${ }^{12}$ Another aspartic protease that gained considerable attention recently is cathepsin D., which it is involved in promoting proliferation, invasion, and metastasis, and is considered a biomarker of aggressive forms of breast cancer that are correlated with poor prognosis. ${ }^{13,14}$ Cathepsin E, on the other hand, has been 
implicated in the regulation of immune responses. ${ }^{15}$ The selective cathepsin E inhibitors, grassystatins A$\mathrm{C}$, have been shown to reduce antigen presentation by dendritic cells, ${ }^{9}$ a process that involves cathepsin $\mathrm{E}$ activity. Given the importance of proteases as therapeutic targets, and based on the aforementioned structural features of the natural aspartic protease inhibitors, several analogues were designed to enhance the potency and selectivity, with potential applications in cancer and Alzheimer's disease. ${ }^{16-18}$ In our ongoing search for novel protease inhibitors from marine cyanobacteria, herein we describe the isolation, characterization and biological evaluation of tasiamide $F(\mathbf{1})$, a novel inhibitor of cathepsins $D$ and $E$ from a marine cyanobacterium Lyngbya sp.

\section{Results and discussion}

\subsection{Isolation and structure determination}

Samples of the cyanobacterium Lyngbya sp. were collected from patch reefs in Cocos Lagoon, Guam. The freeze dried sample was subjected to solvent extraction with 1:1 EtOAc:MeOH. The non-polar extract was then partitioned between EtOAc and $\mathrm{H}_{2} \mathrm{O}$. The EtOAc soluble fraction was further fractionated by diol column chromatography eluting with a gradient of increasing polarity starting with DCM-hexanes. The fraction eluted with 1:1 EtOAc:MeOH was further purified by reversed-phase HPLC using $\mathrm{MeCN}-\mathrm{H}_{2} \mathrm{O}$ mixtures of increasing polarity to yield compound 1 (Figure 1).

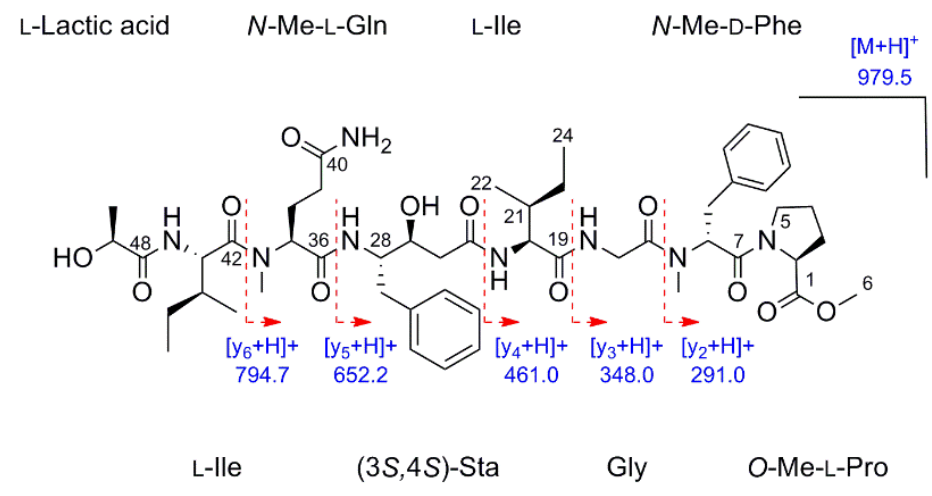

Figure 1. Tasiamide F (1) with ESIMS fragmentation pattern.

The HRESIMS of 1 in the positive mode exhibited a molecular ion peak at $\mathrm{m} / z 1001.5325[\mathrm{M}+\mathrm{Na}]^{+}$ suggesting a molecular formula of $\mathrm{C}_{50} \mathrm{H}_{74} \mathrm{~N}_{8} \mathrm{O}_{12}$ with eighteen degrees of unsaturation. The structure of 1 (Figure 1) was determined using a combination of 1D and 2D NMR techniques. The ${ }^{1} \mathrm{H}$ and ${ }^{13} \mathrm{C}$ NMR spectra suggested the presence of several characteristic signals corresponding to $\alpha$-protons $\left(\sim \delta_{\mathrm{H}} 4-5 \mathrm{ppm}\right)$, exchangeable protons of amides $\left(\sim \delta_{\mathrm{H}} 7-8 \mathrm{ppm}\right)$, two $N$-methyl signals $\left(\sim \delta_{\mathrm{H}} 2.7-2.9 \mathrm{ppm} ; \sim \delta_{\mathrm{C}} 29-30 \mathrm{~Hz}\right)$, and one $O$-methyl $\left(\delta_{\mathrm{H}} 3.62 \mathrm{ppm}\right)$ suggesting a peptide structure. Examination of the $2 \mathrm{D}$ spectra (HSQC, COSY, HMBC, and ROESY) of 1 in DMSO- $d_{6}$ (Table 1 and Supporting Information) revealed the presence of Gly and Ile as proteinogenic amino acids as well as $\mathrm{O}-\mathrm{CH}_{3}-\mathrm{Pro}, \mathrm{N}-\mathrm{CH}_{3}-\mathrm{Phe}, \mathrm{N}-\mathrm{CH}_{3}-\mathrm{Gln}$, lactic acid and a statine unit [4-amino-3-hydroxy-5-phenylpentanoic acid, Ahppa]. The sequence of these units was established by the analysis of HMBC and ROESY spectra and was further confirmed by ESIMS fragmentation (Figure 1). Analysis of the minor set of signals in the proton NMR spectra in three different solvents (DMSO- $d_{6}, \mathrm{CDCl}_{3}$, and $\mathrm{CD}_{3} \mathrm{OD}$; Figures S3, S9, S10) showed the presence of changing 
resonance-doubling ratios (6:1 in $\mathrm{CDCl}_{3}$ and 2:1 in $\left.\mathrm{CD}_{3} \mathrm{OD}\right)$ from aprotic to protic solvents, indicating the presence of conformers in solution.

Comparison of the data with published literature (Figure 2) revealed $\mathbf{1}$ to be a tasiamide B analogue, with key differences between the structures being the replacement of amino acid residues in tasiamide B (2) to $\mathrm{Ala} \rightarrow \mathrm{Gly} ; \mathrm{Leu} \rightarrow \mathrm{Ile} ; \mathrm{Val} \rightarrow \mathrm{Ile}$, which we named tasiamide F (1). Other structurally related cyanobacterial compounds include grassystatin C (3), ${ }^{9}$ bearing a Leu-derived statine core, and tasiamide E (4) and tasiamide (5) which lack the statine unit (Figure 2). ${ }^{10,11,19}$
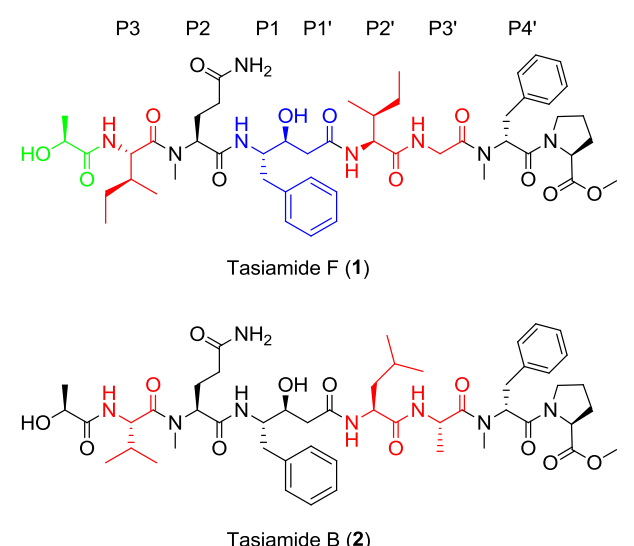

Tasiamide B (2)
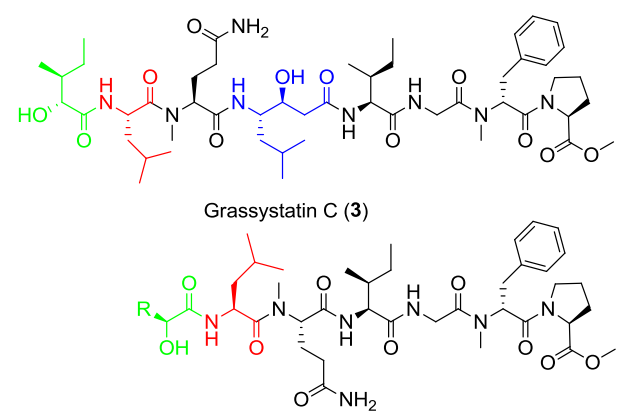

Tasiamide $\mathrm{E} \quad \mathrm{R}=$ iso-butyl $(4)$

Tasiamide $\quad \mathrm{R}=$ sec-butyl $(5)$

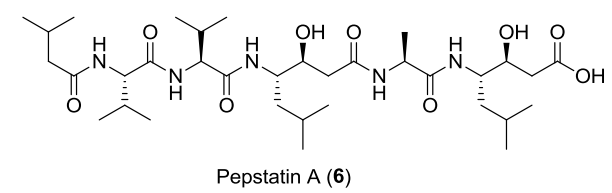

Figure 2. Tasiamide F (1) with binding site nomenclature and other structurally related cyanobacterial compounds (2-5). The differences in structures (2-5) relative to $\mathbf{1}$ are highlighted. Pepstatin A (6) is a natural aspartic protease inhibitor produced by Actinomycetes.

To establish the absolute configuration, a portion of $\mathbf{1}(100 \mu \mathrm{g})$ was hydrolyzed using $6 \mathrm{~N} \mathrm{HCl}\left(110{ }^{\circ} \mathrm{C}\right.$, $24 \mathrm{~h}$ ) and analyzed by chiral HPLC-MS. The analyses revealed retention times corresponding to L-Pro, $\mathrm{N}$ Me-D-Phe, L-Ile, $N$-Me-L-Gln by comparison with authentic standards. The configuration of lactic acid was examined by chiral HPLC revealing the presence of L-lactic acid. To determine the configuration of the statine unit, modified Marfey's analysis ${ }^{20,21}$ was carried out and tasiamide B (2) was used as a standard to liberate the $(4 S) \gamma$-amino acid (mixture of $3 S, 4 S$ and $3 R, 4 S$ due to potential dehydration and 
rehydration). Portions of the hydrolysates of $\mathbf{1}$ and $\mathbf{2}$ were derivatized with both L-FDLA and DL-FDLA and the retention times were compared. The analysis revealed $S$ configuration at C-28. The relative configuration of the Phe-derived statine unit was established based on NMR analysis of the coupling constants of the methylene protons at C-26 to the hydroxy methine at C-27. ${ }^{22}$ The downfield methylene proton $\mathrm{H}-26\left(\delta_{\mathrm{H}} 2.30\right)$ showed a larger coupling $(J 9.5 \mathrm{~Hz})$ to $\mathrm{H}-27$ compared to the upfield methylene proton $\left(\delta_{\mathrm{H}} 2.16\right)(J 3.8 \mathrm{~Hz})$, suggesting $3 S, 4 S$ configuration (recorded in DMSO- $\left.d_{6}\right)$. Similar coupling constants were observed when ${ }^{1} \mathrm{H}$ NMR data were recorded in $\mathrm{CDCl}_{3}\left(\mathrm{H}-26 ; \delta_{\mathrm{H}} 2.50, J 8.2 \mathrm{~Hz}\right)$ and $(\mathrm{H}-$ $26 ; \delta_{\mathrm{H}} 2.35, J 4.8 \mathrm{~Hz}$ ), further supporting $3 S, 4 S$ configuration.

\subsection{Biological evaluation}

The similarity of tasiamide $\mathrm{F}(\mathbf{1})$, in terms of its structure and in particular the presence of a statine unit, to the natural aspartic protease inhibitor pepstatin A (6) and other related marine cyanobacterial natural products (Figure 2), suggested that $\mathbf{1}$ might also have aspartic protease inhibitory activity. To evaluate the antiproteolytic activity, tasiamides F and B, $\mathbf{1}$ and $\mathbf{2}$, were tested in vitro side by side against cathepsins D and E, and BACE1 (Figure 3). Both compounds exhibited a low nanomolar inhibitory activity against cathepsins D and E (Table 2); indicating that tasiamides $\mathbf{1}$ and $\mathbf{2}$ are $\sim 30$-fold more potent against cathepsin D compared with grassystatin $\mathrm{C}(1.62 \mu \mathrm{M})$, while the cathepsin E inhibitory activity is similar (grassystatin C: $42.9 \mathrm{nM}$ ). ${ }^{9}$ Grassystatins A-C, bearing the Leu-derived statine unit, are more selective towards cathepsin E inhibition ( 20- to 38- fold). ${ }^{9}$ Likewise, several designed tasiamide B analogues bearing the Phe-derived statine unit are more selective towards inhibiting cathepsin $\mathrm{D},{ }^{16}$ thus demonstrating that the selectivity can be tuned and these structural scaffolds can serve as a starting point for further development of selective aspartic protease inhibitors. When tested against BACE1, an enzyme involved in the pathogenesis of Alzheimer's disease, ${ }^{12}$ tasiamide F (1) was found to 12-30-fold less potent in inhibiting this enzyme when compared to cathepsins D and E (Table 2). Interestingly, despite the minor structural differences, $\mathbf{2}$ was $\sim 8$ fold more potent in inhibiting BACE1 compared to $\mathbf{1}$. Based on previous SAR and molecular docking studies it has been shown that Phe, Ala, Leu, and Val in tasiamide B (2) are critical for BACE1 activity and significantly affect the inhibition through hydrophobic interactions with the receptor's pocket. ${ }^{17}$ Therefore, minor modifications in these residues might partly be responsible for the altered activity against BACE1 as seen for $\mathbf{1}$. 

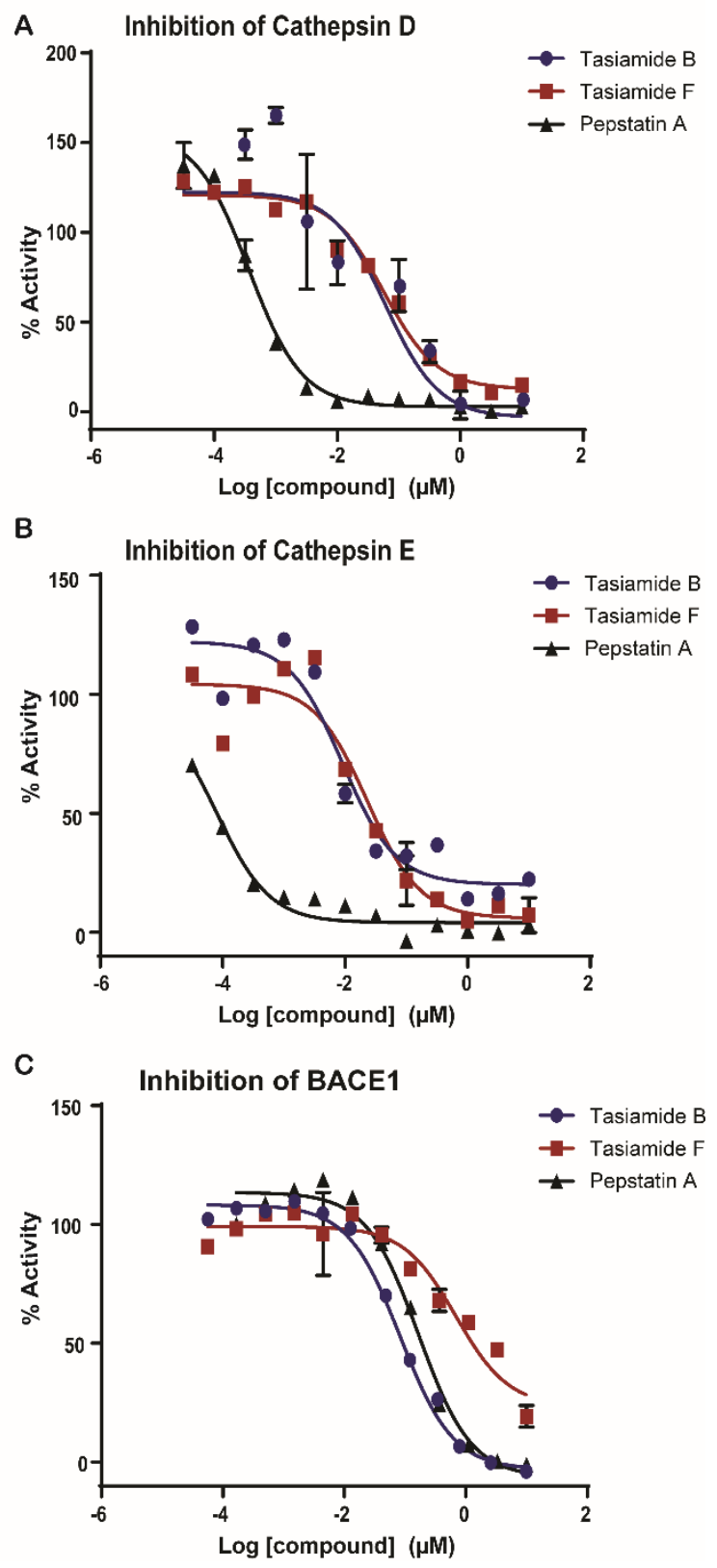

Figure 3. Dose-response curves for tasiamide F (1) and tasiamide B (2) and positive controls against (A) cathepsin D, (B) cathepsin E and (C) BACE1. The dose-response is presented as \% fold inhibition against solvent control (DMSO).

\subsection{Molecular docking}

In order to provide some insight to the structural basis of $\mathbf{1}$ and $\mathbf{2}$, molecular docking experiments were carried out using AutoDock Vina. ${ }^{23}$ The crystal structure of pepstatin A bound to cathepsin D (PDB:

$1 \mathrm{LYB})^{24}$ was used for docking. Pepstatin A was successfully redocked into cathepsin D before attempting to dock tasiamides B (2) and F (1) (Figure S1). Compounds 1 and 2 were then docked (PDB: 1LYB) ${ }^{24}$ 
and the interactions between each of the compounds and the receptor were examined (Figure 4-A, B). Despite the minor differences in structure of $\mathbf{1}$ and $\mathbf{2}$, molecular docking highlights similar binding modes for both compounds within the binding pocket of cathepsin D. It has also been previously established that cathepsin $\mathrm{D}$ has preference for hydrophobic residues at $\mathrm{P} 2^{26}$ therefore we evaluated the interaction between Gln at P2 position within the two structures and the residues at the binding pocket of each receptor. In the docked structure of $\mathbf{1}$ and $\mathbf{2}$ into cathepsin D (Figure 4-A, B), Gln was found to be curled down avoiding the interactions with Ser residues, thus partly explaining the potency towards cathepsin D inhibition. 1 and $\mathbf{2}$ were also docked into a homology model of cathepsin E (Figure 4-C, D) since the only published crystal structure that is available is for an early activation intermediate (PDB: 4PEP). ${ }^{25}$ When 1 and 2 were docked into cathepsin E (Figure 4-C, D), Gln at P2 was found in close proximity to the polar residues within the binding pocket such as Asp 43 and Thr 88 in case of 1 and Asp 43 and Ser 46, in case of 2. This could at least in part explain the potency towards cathepsin E. It was noted that the residue at $\mathrm{P} 3$ and lactic acid in tasiamide B structure is curled down in close proximity to the amino acid residues Thr 88, Gly 87, and Tyr 86 in cathepsin E (Figure 4-D) but that was not the case in 1 (Figure 4-C).

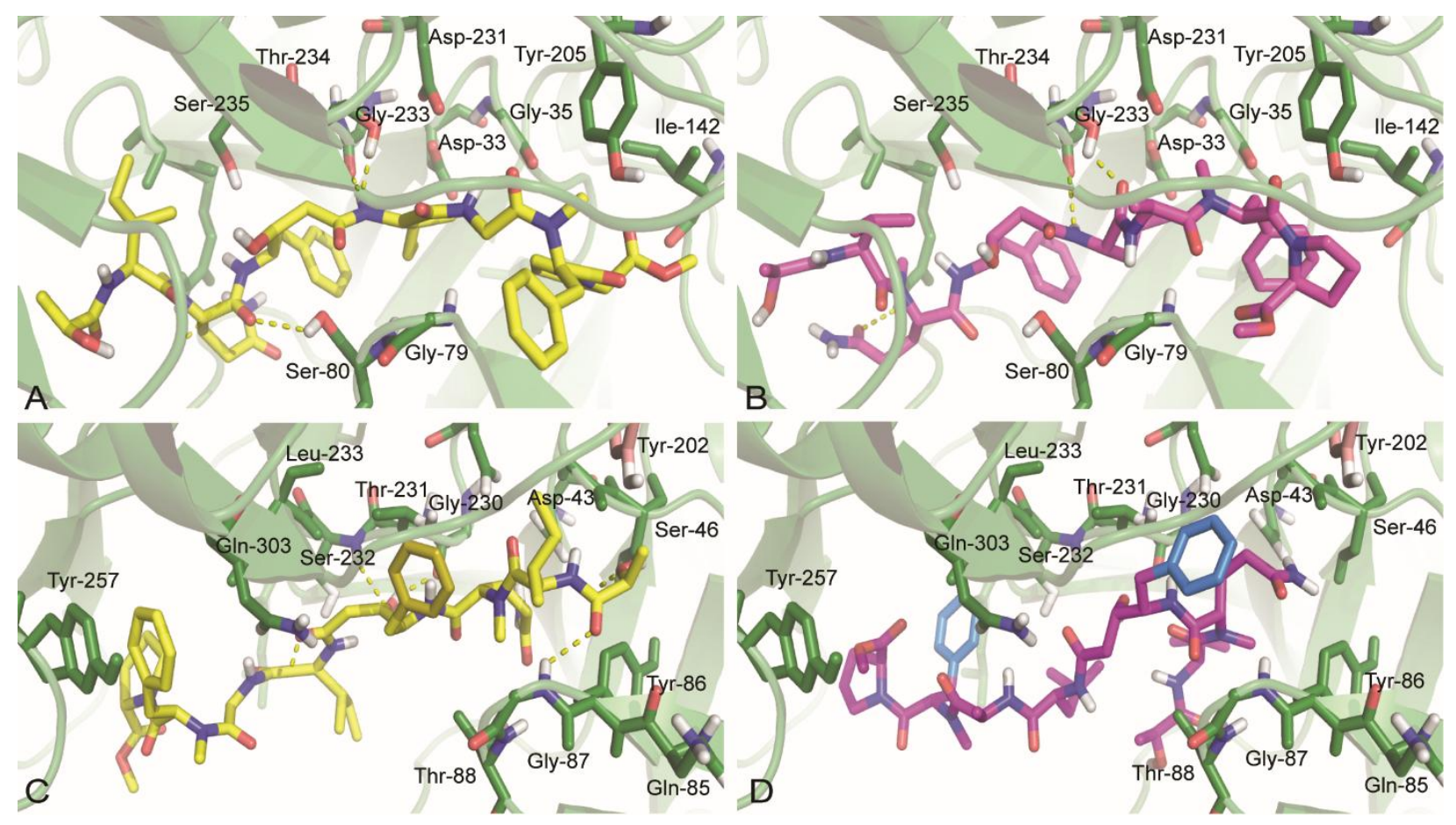

Figure 4. Docked structures of (A) tasiamide F (1) and (B) tasiamide B (2) in cathepsin D (1LYB) (green). Docked structures of (C) tasiamide F (1) and (D) tasiamide B (2) in cathepsin E. Polar contacts are shown as dotted lines.

\section{Conclusion}

The implication of dysregulated protease activity in many diseases highlights the importance of proteases as therapeutic targets. The discovery of tasiamide F (1), a novel analogue of tasiamide B (2), adds to the 
family of statine-containing aspartic protease inhibitors from marine cyanobacteria. We evaluated its inhibitory activity against cathepsin D, cathepsin E and BACE1 compared to tasiamide B (2) and provided insight into the structural basis underlying its preferential activity against cathepsins $\mathrm{D}$ and $\mathrm{E}$ by molecular docking experiments. Tasiamide $\mathrm{F}(\mathbf{1})$ is a potent inhibitor of cathepsins $\mathrm{D}$ and $\mathrm{E}$ with $\mathrm{IC}_{50}$ values in the nanomolar range, whereas the BACE1 activity is largely dialed out. This class of compounds might be developed into probes to further investigate the biology of cathepsin D/E mediated processes and serve as a starting point for the design and development of more potent and selective leads with therapeutic potential.

\section{Experimental section}

\subsection{General experimental procedure}

The optical rotation was measured using a Perkin-Elmer 341 polarimeter. ${ }^{1} \mathrm{H},{ }^{13} \mathrm{C}$ and $2 \mathrm{D}$ NMR spectra were obtained in DMSO- $d_{6}$ using Agilent VNMRS-600 MHz, 5-mm cold probe spectrometer. The spectra were referenced using the residual solvent signal $\left[\delta_{\mathrm{H} / \mathrm{C}} 2.5 / 39.5\left(\mathrm{DMSO}-d_{6}\right)\right]$. The HRESIMS data were obtained in the positive mode using Agilent LC-TOF mass spectrometer equipped with APCI/ESI multimode ion source detector. LCMS data were obtained using API 3200 (Applied Biosystems) equipped with an HPLC system (Shimadzu). ESI-MS/MS data were obtained using ThermoFinnigan (San Jose, CA) LCQ DECA with electrospray ionization (ESI).

\subsection{Biological material}

Pink fluffy Lyngbya sp. NIH code 399 was collected from Val's reef, a patch reef in Cocos Lagoon, Guam on December 6, 2001. Voucher specimens are retained at the Smithsonian Marine Station at Ft. Pierce.

\subsection{Extraction and isolation}

The freeze dried sample of cyanobacterium Lyngbya sp. was subjected to non-polar extraction with 1:1 EtOAc: $\mathrm{MeOH}$ and polar extraction with 1:1 EtOH: $\mathrm{H}_{2} \mathrm{O}$. The non-polar extract was subsequently partitioned between EtOAc and $\mathrm{H}_{2} \mathrm{O}$. The water fraction was combined with polar extract and further partitioned between $\mathrm{BuOH}$ and $\mathrm{H}_{2} \mathrm{O}$. The EtOAc fraction was fractionated using diol column chromatography applying a gradient of increasing polarity (9:1 Hexanes:DCM, 20:1 DCM:EtOAc, EtOAc, 1:1 EtOAc:MeOH, MeOH). The fraction eluting with 1:1 EtOAc:MeOH was further purified by reversed phase HPLC [Luna 5u Phenyl-Hexyl, $250 \times 10.0 \mathrm{~mm}$; flow rate, $2.0 \mathrm{~mL} / \mathrm{min}$; PDA detection 200-800 nm] using a linear $\mathrm{MeOH}-\mathrm{H}_{2} \mathrm{O}$ gradient (70-100\% MeOH over 15 min, 100\% $\mathrm{MeOH}$ for $10 \mathrm{~min})$ to afford a compound $\mathrm{mix}(2.8 \mathrm{mg})$ which was further purified under multiple HPLC conditions [Synergi Hydro 4u-RP, $250 \times 10.0 \mathrm{~mm}$; flow rate, $2.0 \mathrm{~mL} / \mathrm{min}$; PDA detection $200-800 \mathrm{~nm}$ ] using a linear $\mathrm{MeCN}-\mathrm{H}_{2} \mathrm{O}$ gradient $(10-100 \% \mathrm{MeOH}$ over $20 \mathrm{~min}, 100 \% \mathrm{MeOH}$ for $10 \mathrm{~min}$ ) and (column, Synergi Fusion, $250 \times 10.0 \mathrm{~mm}$; flow rate, $2.0 \mathrm{~mL} / \mathrm{min}$; PDA detection 200-800 nm] using a linear $\mathrm{MeCN}-\mathrm{H}_{2} \mathrm{O}$ gradient (10-100\% MeCN over $15 \mathrm{~min}, 100 \% \mathrm{MeOH}$ for 10 $\min )$ to afford $1\left(1.3 \mathrm{mg}, t_{\mathrm{R}} \sim 15 \mathrm{~min}\right)$.

Tasiamide F (1): colorless amourphous solid; $[\alpha]^{20}{ }_{\mathrm{D}}-13.3\left(c\right.$ 0.09, MeOH); NMR data, ${ }^{1} \mathrm{H}$ NMR, ${ }^{13} \mathrm{C}$ NMR, COSY, HSQC , HMBC, ROESY in DMSO- $d_{6}$, see Table 1 and Supporting information; HRESIMS $m / z 1001.5325[\mathrm{M}+\mathrm{Na}]^{+}$(calcd for $\mathrm{C}_{50} \mathrm{H}_{74} \mathrm{~N}_{8} \mathrm{O}_{12} \mathrm{Na}$ ).

\subsection{Absolute configuration}

\subsubsection{Acid hydrolysis and chiral $\alpha$-amino acid analysis by LC-MS}


A sample of compound $1(100 \mu \mathrm{g})$ was hydrolyzed with $6 \mathrm{~N} \mathrm{HCl}(0.2 \mathrm{ml})$ at $110{ }^{\circ} \mathrm{C}$ for $24 \mathrm{~h}$. The hydrolysate was concentrated to dryness, reconstituted in $100 \mu \mathrm{l}$ of $\mathrm{H}_{2} \mathrm{O}$, and then analyzed by chiral HPLC [Chirobiotic TAG $(250 \times 4.6 \mathrm{~mm})$, Supelco; solvent: $\mathrm{MeOH}-10 \mathrm{mM} \mathrm{NH}_{4} \mathrm{OAc}(40: 60, \mathrm{pH}$ 5.48); flow rate $0.5 \mathrm{ml} / \mathrm{min}$; detection by ESIMS in positive ion mode MRM scan)]. L-Pro, $N$-Me-DPhe, and $N$-Me-L-Gln eluted at $t_{\mathrm{R}} 14.0,42.6$, and $7.1 \mathrm{~min}$, respectively. The retention times $\left(t_{\mathrm{R}}\right.$, min; MRM ion pair, parent $\rightarrow$ product) of the authentic amino acids were as follows: L-Pro $(14.0 ; 116 \rightarrow 70)$, D-Pro (35.5), $N$-Me-L-Phe (24.2; 180.1 $\rightarrow 134.1), N$-Me-D-Phe (42.6), $N$-Me-L-Gln $(7.1 ; 162 \rightarrow 98), N$ Me-D-GIn (20.3). The compound-dependent MS parameters were as follows: Pro: DP 32.4, EP 4, CE 21.8, CXP 2.8; $N$-Me-Phe: DP 29, EP 4, CE 20, CXP 3; $N$-Me-Gln: DP 32, EP 7, CE 17, CXP 3. The source and gas-dependent MS parameters were as follows: CUR 50, CAD medium, IS 5500, TEM 750 , GS1 65, GS2 65. In order to separate Ile isomers, the mobile phase was changed to $\mathrm{MeOH}-10$ $\mathrm{mM} \mathrm{NH} \mathrm{N}_{4} \mathrm{OAc}(90: 10, \mathrm{pH} 5.55)$. The acid hydrolysate of 1 showed a peak corresponding to L-Ile $\left(t_{\mathrm{R}}\right.$ 11.6). The retention times $\left(t_{\mathrm{R}}, \min\right.$; MRM ion pair, parent $\rightarrow$ product $)$ of the authentic amino acids were as follows: L-Ile (11.6; 132 $\rightarrow 86)$, L-allo-Ile (13.0), D-Ile (43.8), D-allo-Ile (38.6). This assignment was confirmed by co-injecting the hydrolysate with each standard.

The lactic acid unit in the hydrolysate was examined under different HPLC conditions [Chirex 3126 (D)-penicillamine $(250 \times 4.6 \mathrm{~mm}) 5$ micron (Phenomenex); solvent: $2 \mathrm{mM} \mathrm{CuSO}_{4}$; flow rate 1 $\mathrm{ml} / \mathrm{min}$; detection by UV $(254 \mathrm{~nm})]$. L-Lactic acid from the hydrolysate eluted at $t_{\mathrm{R}} 32 \mathrm{~min}$. The retention times $\left(t_{\mathrm{R}}, \mathrm{min}\right)$ of the authentic standards were as follows: L-Lactic acid (32.0), D-Lactic acid (39.0).

\subsubsection{Modified Marfey's analysis}

Samples of 1 and $2(35 \mu \mathrm{g})$ were subjected to acid hydrolysis at $110^{\circ} \mathrm{C}$ for $24 \mathrm{~h}$ using $6 \mathrm{~N} \mathrm{HCl}$. The hydrolysate was derivatized with both L-FDLA and DL-FDLA through the addition of $10 \mu 1$ of $1 \mathrm{M}$ $\mathrm{NaHCO}_{3}$ followed by $50 \mu \mathrm{l}$ of $1 \%$ acetone solution of L-FDLA or DL-FDLA. The contents were mixed and heated over a hot plate at $30-40{ }^{\circ} \mathrm{C}$ for an hour with frequent mixing. The reaction mixture was then cooled at room temperature, acidified with $2 \mathrm{~N} \mathrm{HCl}(5 \mu \mathrm{l})$, dried, and re-suspended in 1:1 $\mathrm{MeCN}: \mathrm{H}_{2} \mathrm{O}$. Aliquots were analyzed by reversed-phase HPLC [Alltima HP C18 HL $(250 \times 4.6 \mathrm{~mm})$, $5 \mu \mathrm{m}$, Alltech; flow rate $0.5 \mathrm{ml} / \mathrm{min}$; detection by ESIMS in negative ion mode (MRM scan, $502 \rightarrow 442$ )] using a linear gradient of $\mathrm{MeOH}$ in $\mathrm{H}_{2} \mathrm{O}$ (both containing $0.1 \% \mathrm{HCOOH}, 40-100 \%$ $\mathrm{MeOH}$ over $50 \mathrm{~min})$. The MS parameters used were as follows: DP -32, EP -7, CE -33, CEP -30.75, CXP -1, CUR 40, CAD High, IS -4500, TEM 650, GS1 65, GS2 65. The retention times $\left(t_{\mathrm{R}}, \mathrm{min}\right.$; MRM ion pair, parent $\rightarrow$ product) of the standard (tasiamide B (2) hydrolysate derivatized with LFDLA and DL-FDLA) were as follows: Tasiamide B- L-FDLA (36.9) and tasiamide B- DL-FDLA $(36.9,45.0)$. The retention time of tasiamide $\mathrm{F}(\mathbf{1})$ hydrolysate derivatized with L-FDLA was 36.9 suggesting the same configuration as for tasiamide B.

\subsection{In vitro protease inhibition assays}

Cathepsin D (Enzo Life Sciences, Farmingdale, NY) and cathepsin E (R\&D systems) were freshly prepared in the assay buffer $[100 \mathrm{mM} \mathrm{NaOAc} / 100 \mathrm{mM} \mathrm{NaCl}(\mathrm{pH} 3.5)]$. The enzyme solution was added in each well such that the final concentration was $2 \mu \mathrm{g} / \mathrm{ml}$ for cathepsin D and $0.05 \mu \mathrm{g} / \mathrm{ml}$ for cathepsin $\mathrm{E}$. This was followed by the addition of various concentrations (half $\log$ dilutions starting from $10 \mu \mathrm{M}$ final concentration) of test compounds (tasiamide $\mathrm{B}$, tasiamide $\mathrm{F}$, and pepstatin $\mathrm{A}$ ) dissolved in DMSO. The plate was then incubated at room temperature for $15 \mathrm{~min}$. Subsequently, substrate solution Mca-Gly-Lys-Pro-Ile-Leu-Phe-Phe-Arg-Leu-Lys-(Dnp)-D-Arg- $\mathrm{NH}_{2}$ [(Enzo Life Sciences $) ; \mathrm{Mca}=(7-$ methoxycoumarin-4-yl)acetyl; Dnp = 2,4,-dinitrophenyl $]$ prepared in DMSO 
was then added such that the final concentration was $10 \mu \mathrm{M}$. The enzyme activities were monitored by measuring the increase in fluorescence signal from the fluorescently labeled substrate every 5 min for $120 \mathrm{~min}$ (Ex $320 \mathrm{~nm}, \mathrm{Em} 405 \mathrm{~nm}$ ) using SpectraMax plate reader.

The antiproteolytic activity assay against BACE1 was carried out by Reaction Biology Corp. Compounds 1 and 2 were tested in 12-dose $\mathrm{IC}_{50}$ with 3-fold serial dilution starting at $100 \mu \mathrm{M}$ against BACE1 in duplicate. The control compound was tested in a 10-dose $\mathrm{IC}_{50}$ with 3 -fold serial dilution starting at $10 \mu \mathrm{M}$. The protease activities were monitored as a time-course measurement of the increase in fluorescence signal from fluorescently-labeled peptide substrate and the initial linear portion of the slope (signal/min) was analyzed.

\subsection{Molecular docking}

Molecular docking of $\mathbf{1}$ and $\mathbf{2}$ was carried out using AutoDock Vina 1.0. ${ }^{23}$ The compounds were docked into the crystal structure of cathepsin D bound to pepstatin A (PDB ID: 1LYB). ${ }^{24}$ The 3D structures of $\mathbf{1}$ and $\mathbf{2}$ were obtained and then energetically minimized using Chem3D Pro 12.0 software [Cambridge Corporation, USA, 2010]. The receptor was prepared by removing water molecules and adding polar hydrogens using Pymol and Autodock tools. Receptor grid was then generated using Autodock tools. In structures of $\mathbf{1}$ and $\mathbf{2}$, all the bonds were considered rotatable except the amide bonds and the rings. The docked structures of $\mathbf{1}$ and $\mathbf{2}$ into cathepsin D were then examined and the interactions were analyzed using Pymol software. Pepstatin A (6) was also docked into cathepsin D and was compared with the X-ray structure of pepstatin A bound to cathepsin D (Figure S1). A homology model of cathepsin E was used since the only crystal structure available is for an activation intermediate (PDB: 4PEP). ${ }^{25}$ More details regarding the homology model are available in the experimental section of reference 7.

\section{Acknowledgement}

The research was supported by the National Institutes of Health grant R01CA172310. We acknowledge Dr. Jason Kwan for providing the homology model of cathepsin E. This is contribution \#1031 of the Smithsonian Marine Station at Fort Pierce.

\section{References}

[1] Kwan, J.C.; Liu, Y.; Ratnayake, R.; Hatano, R.; Kuribara, A.; Morimoto, C.; Ohnuma, K.; Paul, V.J.; Ye, T.; Luesch, H. Chem Bio Chem. 2014, 15, 799.

[2] Miller, B.; Friedman, A.J.; Choi, H.; Hogan, J.; McCammon, J.A.; Hook, V.; Gerwick, W.H. J Nat Prod. 2014, 77, 92.

[3] Taori, K.; Matthew, S.; Rocca, J.R.; Paul, V.J.; Luesch, H. J Nat Prod. 2007, 70, 1593.

[4] Kwan, J.C.; Taori, K.; Paul, V.J.; Luesch, H. Mar Drugs. 2009, 7, 528.

[5] Luo, D.; Chen, Q.Y.; Luesch, H. J Org Chem. 2016, 81, 532.

[6] Salvador, L.A.; Taori, K.; Biggs, J.S.; Jakoncic, J.; Ostrov, D.A.; Paul, V.J.; Luesch, H. J Med Chem. 2013, 56, 1276.

[7] Morishima, H.; Takita, T.; Aoyagi, T.; Takeuchi, T.; Umezawa, H. J Antibiot. 1970, 23, 263.

[8] Umezawa, H.; Aoyagi, T.; Morishima, H.; Matsuzaki, M.; Hamada, M. J Antibiot. 1970, 23, 259.

[9] Kwan, J.C.; Eksioglu, E.A.; Liu, C.; Paul, V.J.; Luesch, H. J Med Chem. 2009, 52, 5732. 
[10] Williams, P.G.; Yoshida, W.Y.; Moore, R.E.; Paul, V.J. J Nat Prod. 2003, 66, 1006.

[11] Sun, T.; Zhang, W.; Zong, C.; Wang, P.; Li, Y. J Pept Sci. 2010, 16, 364.

[12] Vassar, R.; Bennett, B. D.; Babu-Khan, S.; Kahn, S.; Mendiaz, E. A.; Denis, P.; Teplow, D. B.; Ross, S.; Amarante, P.; Loeloff, R.; Luo, Y.; Fisher, S.; Fuller, J.; Edenson, S.; Lile, J.; Jarosinski, M. A.; Biere, A. L.; Curran, E.; Burgess, T.; Louis, J. C.; Collins, F.; Treanor, J.; Rogers, G.; Citron, M. Science. 1999, 286,735 .

[13] Ohri, S. S.; Vashishta, A.; Vetvickova, J.; Fusek, M.; Vetvicka, V. Int J Biol Macromolec. 2007, 41, 204.

[14] Garcia, M.; Platet, N.; Liaudet, E.; Laurent, V.; Derocq, D.; Brouillet, J.P.; Rochefort, H. Stem Cells 1996, 14,642 .

[15] Zaidi, N.; Hermann, C.; Hermann, T.; Kalbacher, H. Biochem Biophys Res Commun. 2008, 377, 327.

[16] Liu, Y.; Zhang, W.; Li, L.; Salvador, L.A.; Chen, T.; Chen, W.; Felsenstein, K.M.; Ladd, T.B.; Price, A.R.; Golde, T.E.; He, J.; Xu, Y.; Li, Y.; Luesch, H. J Med Chem. 2012, 55, 10749.

[17] Liu, J.; Chen, W.; Xu, Y.; Ren, S.; Zhang, W.; Li, Y. Bioorg Med Chem. 2015, 23, 1963.

[18] Zhang, W.; Sun, T.; Ma, Z.; Li, Y. Mar Drugs 2014, 12, 2308.

[19] Mevers, E.; Haeckl, F.P.; Boudreau, P.D.; Byrum, T.; Dorrestein, P.C.; Valeriote, F.A.; Gerwick, W.H. J Nat Prod. 2014, 77, 969.

[20] Marfey, P. Carlsberg Res Commun. 1984, 49, 591.

[21] Harada, K.; Fjuii, K.; Hayashi, K.; Suzuki, M.; Ikai, Y.; Oka, H. Tetrahedron Lett. 1996, 37, 3001.

[22] Preciado, A.; Williams, P.G. J Org Chem. 2008, 73, 9228.

[23] Trott, O.; Olson, A. J. J Comput Chem. 2010, 31, 455.

[24] Baldwin, E. T.; Bhat, T. N.; Gulnik, S.; Hosur, M. V.; Sowder, R. C.; Cachau, R. E.; Collins, J.; Silva, A. M.; Erickson, J. W. Proc Natl Acad Sci U.S.A. 1993, 90, 6796.

[25] Ostermann, N.; Gerhartz, B.; Worpenberg, S.; Trappe, J.; Eder, J. J Mol Biol. 2004, 342, 889.

[26] Rao-Naik, C.; Guruprasad, K.; Batley, B.; Rapundalo, S.; Hill, J.; Blundell, T.; Kay, J.; Dunn, B. M. Struct Funct Bioinf. 1995, 22, 168. 
Table 1. NMR spectral data for tasiamide F (1) at $600 \mathrm{MHz}\left({ }^{1} \mathrm{H}\right)$ in DMSO- $d_{6}$

\begin{tabular}{|c|c|c|c|c|c|}
\hline \multirow{10}{*}{$\begin{array}{l}\overline{\mathrm{C} / \mathrm{H} \text { no. }} \\
O \text {-Me-Pro }\end{array}$} & & $\delta_{\mathrm{H}}(J$ in $\mathrm{Hz})$ & $\delta_{\mathrm{C}}$ & ${ }^{1} \mathrm{H}-{ }^{-1} \mathrm{H} \mathrm{COSY}$ & HMBC \\
\hline & 1 & & $172.1, \mathrm{~s}$ & & \\
\hline & 2 & $4.25, \mathrm{dd}(8.4,6.2)$ & $58.7, \mathrm{~d}$ & $\mathrm{H}-3 \mathrm{a}, \mathrm{H}-3 \mathrm{~b}$ & $1,3,4$ \\
\hline & $3 a$ & $2.15, \mathrm{~m}$ & $28.4, \mathrm{t}$ & & 1 \\
\hline & $3 b$ & $1.71, \mathrm{~m}$ & & & $1,2,4,5$ \\
\hline & $4 \mathrm{a}$ & $1.78, \mathrm{~m}$ & $24.6, \mathrm{t}$ & & \\
\hline & $5 b$ & $1.73, \mathrm{~m}$ & & & \\
\hline & $5 \mathrm{a}$ & $3.32, \mathrm{~m}$ & $46.3, \mathrm{t}$ & & $2,3,4$ \\
\hline & $5 b$ & $3.24, \mathrm{~m}$ & & $\mathrm{H}-4 \mathrm{a}$ & 3,4 \\
\hline & 6 & $3.62, \mathrm{~s}$ & $51.7, \mathrm{q}$ & & 1 \\
\hline \multirow[t]{9}{*}{$N$-Me-Phe } & 7 & & $167.7, \mathrm{~s}$ & & \\
\hline & 8 & $5.41, \mathrm{t}(7.5)$ & $55.7, \mathrm{~d}$ & H-9a, H-9b & $7,9,10,16$ \\
\hline & $9 \mathrm{a}$ & $3.13, \mathrm{dd}(-13.5,7.5)$ & $34.2, \mathrm{t}$ & $\mathrm{H}-8, \mathrm{H}-9 \mathrm{~b}$ & $7,8,10,11 / 15$ \\
\hline & $9 \mathrm{~b}$ & $2.68, \mathrm{dd}(-13.5,7.5)$ & & H-8, H-9a & $7,8,10,11 / 15$ \\
\hline & 10 & & $137.8, \mathrm{~s}$ & & \\
\hline & $11 / 15$ & $7.19, \mathrm{~m}$ & 129.2, d & H-12/14 & $9,11 / 15,12 / 14,13$ \\
\hline & $12 / 14$ & $7.21, \mathrm{~m}$ & $128.0, \mathrm{~d}$ & H-11/15 & $10,12 / 14$ \\
\hline & 13 & $7.15, \mathrm{~m}$ & 126.1, d & & $11 / 15$ \\
\hline & 16 & $2.90, \mathrm{~s}$ & $29.4, \mathrm{q}$ & & 8,17 \\
\hline \multirow[t]{4}{*}{ Gly } & 17 & & $168.1, \mathrm{~s}$ & & \\
\hline & $18 \mathrm{a}$ & $4.05, \mathrm{~m}$ & $40.2, \mathrm{t}$ & H_18b, NH & 17,19 \\
\hline & $18 \mathrm{~b}$ & $3.72, \mathrm{~m}$ & & $\mathrm{H}-18 \mathrm{a}, \mathrm{NH}$ & 17,19 \\
\hline & $\mathrm{NH}$ & $8.01, \mathrm{t}(6.6)$ & & $\mathrm{H}-18 \mathrm{a}, \mathrm{H}-18 \mathrm{~b}$ & 19 \\
\hline \multirow[t]{8}{*}{ Ile } & 19 & & $171.1, \mathrm{~s}$ & & \\
\hline & 20 & $4.21, \mathrm{dd}(9.4,6.2)$ & $56.8, \mathrm{~d}$ & $\mathrm{NH}$ & $19,21,22,23$ \\
\hline & 21 & $1.71, \mathrm{~m}$ & $36.7, \mathrm{~d}$ & $\mathrm{H}_{3}-22$ & \\
\hline & 22 & $0.82, \mathrm{~m}$ & $15.3, \mathrm{q}$ & $\mathrm{H}-21, \mathrm{H}-23 \mathrm{a}$ & 20 \\
\hline & $23 a$ & $1.44, \mathrm{~m}$ & $24.1, \mathrm{t}$ & $\mathrm{H}-23 \mathrm{~b}, \mathrm{H}_{3}-22$ & 21,22 \\
\hline & $23 \mathrm{~b}$ & $1.05, \mathrm{~m}$ & & $\mathrm{H}-21, \mathrm{H}-23 \mathrm{a}$ & $21,22,24$ \\
\hline & 24 & $0.79, \mathrm{~m}$ & $11.2, \mathrm{q}$ & $\mathrm{H}-23 \mathrm{a}, \mathrm{H}-23 \mathrm{~b}$ & 21,23 \\
\hline & $\mathrm{NH}$ & $7.86, \mathrm{~d}(8.4)$ & & $\mathrm{H}-20$ & 25 \\
\hline \multirow[t]{13}{*}{ Ahppa } & 25 & & 170.6, s & & \\
\hline & $26 \mathrm{a}$ & $2.30, \mathrm{dd}(-14.0,9.5)$ & $40.0, \mathrm{t}$ & $\mathrm{H}-26 \mathrm{~b}, \mathrm{H}-27$ & 25 \\
\hline & $26 \mathrm{~b}$ & 2.16 , dd $(-14.0,3.8)$ & & $\mathrm{H}-26 \mathrm{a}, \mathrm{H}-27$ & $25,27,28$ \\
\hline & 27 & $3.85, \mathrm{~m}$ & $67.9, \mathrm{~d}$ & $\mathrm{H}-26 \mathrm{a}, \mathrm{H}-26 \mathrm{~b}$ & \\
\hline & 28 & $3.99, \mathrm{~m}$ & $54.2, \mathrm{~d}$ & $\mathrm{H}-29 \mathrm{a}, \mathrm{H}-29 \mathrm{~b}, \mathrm{NH}$ & 30 \\
\hline & $29 \mathrm{a}$ & $2.82, \mathrm{~m}$ & $34.2, \mathrm{t}$ & $\mathrm{H}-28, \mathrm{H}-29 \mathrm{~b}$ & $27,28,30,31 / 35$ \\
\hline & $29 \mathrm{~b}$ & $2.62, \mathrm{~m}$ & & $\mathrm{H}-28, \mathrm{H}-29 \mathrm{a}$ & $27,28,30,31 / 35$ \\
\hline & 30 & & $139.0, \mathrm{~s}$ & & \\
\hline & $31 / 35$ & $7.07, \mathrm{~d}(7.2)$ & 128.9, d & $\mathrm{H}-32 / 34$ & 33 \\
\hline & $32 / 34$ & $7.22, \mathrm{~m}$ & $128.0, \mathrm{~d}$ & H-31/35 & 30 \\
\hline & 33 & $7.16, \mathrm{~m}$ & $125.8, \mathrm{~d}$ & & \\
\hline & $\mathrm{OH}$ & $5.09, \mathrm{br}$ & & $\mathrm{H}-27$ & \\
\hline & $\mathrm{NH}$ & $7.39, \mathrm{~d}(9.3)$ & & H-28 & 28,36 \\
\hline \multirow[t]{9}{*}{$N$-Me-Gln } & 36 & & $169.3, \mathrm{~s}$ & & \\
\hline & 37 & $4.93, \mathrm{dd}(9.5,6.2)$ & $55.5, \mathrm{~d}$ & H-38a, H-38b & $36,38,39,42$ \\
\hline & $38 \mathrm{a}$ & $1.95, \mathrm{~m}$ & $24.0, \mathrm{t}$ & $\mathrm{H}-37, \mathrm{H}-38 \mathrm{~b}$ & \\
\hline & $38 \mathrm{~b}$ & $1.74, \mathrm{~m}$ & & $\mathrm{H}-37, \mathrm{H}-38 \mathrm{a}$ & 39 \\
\hline & $39 a$ & $1.95, \mathrm{~m}$ & $31.5, \mathrm{t}$ & & 38,40 \\
\hline & $39 \mathrm{~b}$ & $1.88, \mathrm{~m}$ & & $\mathrm{H}-38 \mathrm{~b}$ & $37,38,40$ \\
\hline & 40 & & $173.5, \mathrm{~s}$ & & \\
\hline & 41 & $2.74, \mathrm{~s}$ & $30.3, \mathrm{q}$ & & 37,42 \\
\hline & $\mathrm{NH}_{2}$ & & & & \\
\hline \multirow[t]{8}{*}{ ILe } & 42 & & $171.8, \mathrm{~s}$ & & \\
\hline & 43 & $4.55, \mathrm{dd}(9.1,7.5)$ & $51.9, \mathrm{~d}$ & $\mathrm{H}-44, \mathrm{NH}$ & $42,44,45,46,48$ \\
\hline & 44 & $1.74, \mathrm{~m}$ & $36.7, \mathrm{~d}$ & & \\
\hline & 45 & $0.82, \mathrm{~m}$ & $15.4, \mathrm{q}$ & H-44 & $43,44,46$ \\
\hline & $46 a$ & $1.47, \mathrm{~m}$ & $23.6, \mathrm{t}$ & $\mathrm{H}-46 \mathrm{~b}, \mathrm{H}_{3}-47$ & $43,44,45,47$ \\
\hline & $46 \mathrm{~b}$ & $1.02, \mathrm{~m}$ & & & \\
\hline & 47 & $0.81, \mathrm{~m}$ & $10.9, \mathrm{q}$ & H-46a, H-46b & \\
\hline & $\mathrm{NH}$ & $7.50, \mathrm{~d}(9.1)$ & & & 42 \\
\hline \multirow[t]{4}{*}{ Lactic acid } & 48 & & $174.1, \mathrm{~s}$ & & \\
\hline & 49 & $3.98, \mathrm{~m}$ & $67.1, \mathrm{~d}$ & $\mathrm{H}_{3}-50$ & 48 \\
\hline & 50 & $1.21, \mathrm{~d}(6.8)$ & $21.2, \mathrm{q}$ & H-49 & 48,49 \\
\hline & $\mathrm{OH}$ & 5.68, br & & & \\
\hline
\end{tabular}


Table 2. $\mathrm{IC}_{50}$ values of tasiamide $\mathrm{F}(\mathbf{1})$, tasiamide B (2), and positive controls against aspartic proteases

\begin{tabular}{|c|c|c|c|c|c|}
\hline & Cathepsin D & Cathepsin E & Selectivity ratio $^{a}$ & BACE1 & Selectivity ratio $^{b}$ \\
\hline Tasiamide F (1) & $57 \mathrm{nM}$ & $23 \mathrm{nM}$ & 2.4 & $690 \mathrm{nM}$ & $12-30$ \\
\hline Tasiamide B (2) & $50 \mathrm{nM}$ & $9.0 \mathrm{nM}$ & 5.5 & $80 \mathrm{nM}$ & $1.6-8.9$ \\
\hline Pepstatin A (6) & $0.53 \mathrm{nM}$ & $0.08 \mathrm{nM}$ & 6.6 & & \\
\hline$\beta$-Secretase inhibitor IV & 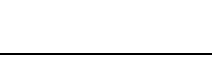 & & & $160 \mathrm{nM}$ & \\
\hline
\end{tabular}

${ }^{\mathrm{a}} \mathrm{IC}_{50} \mathrm{CatD} / \mathrm{IC}_{50}$ CatE. ${ }^{\mathrm{b}} \mathrm{IC}_{50} \mathrm{BACE} 1 / \mathrm{CatD}-\mathrm{E}$ 


\section{Graphical Abstract}

To create your abstract, type over the instructions in the template box below.

Fonts or abstract dimensions should not be changed or altered.

\section{Tasiamide $F$, a potent inhibitor of cathepsins $D$ and $E$ from a marine cyanobacterium}

Fatma H. Al-Awadhi ${ }^{\mathrm{a}, \mathrm{b}}$, Ranjala Ratnayake ${ }^{\mathrm{a}, \mathrm{b}}$, Valerie J. Paul ${ }^{\mathrm{c}}$ and Hendrik Luesch ${ }^{*, \mathrm{a}, \mathrm{b}}$

${ }^{\mathrm{a}}$ Department of Medicinal Chemistry, ${ }^{\mathrm{b}}$ Center for Natural Products, Drug Discovery and Development (CNPD3), University of Florida, Gainesville.

${ }^{\mathrm{C} S}$ Smithsonian Marine Station, Fort Pierce, Florida, USA.

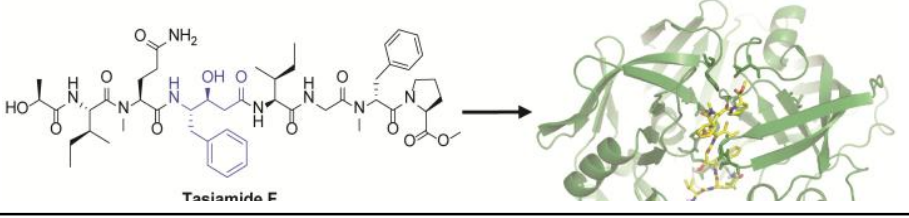

